\title{
Academic Status of Library Staff Members of Large Universities
}

The director of libraries, Lousiana State University, discusses the status of librarians in thirty-seven large universities.

$A^{N}$ academic survey of the institution $\mathrm{A}_{\text {I }}$ represent has been arranged for which has led me to give some thought to the relation of members of the library staff to the faculty and the numerous other employes of the university. What should be their status in the group and, especially, are library staff members to be treated as members of the faculty or are they merely administrative employes? These are questions that should be definitely determined sooner or later. Some may suggest that it is best to "let well enough alone," but the question is bound to come up until there is a definite satisfactory statute, or official rule covering the subject.

In order to ascertain what the practices of the larger institutions are, I directed personal letters to some thirty-five head librarians, all of whom replied and cited conditions existing in their respective universities. Information was secured in regard to two other institutions, so this paper summarizes the practices of thirty-seven large universities, all of which have libraries in excess of 200,000 volumes.

Only eleven institutions have specific regulations on this matter and but four definitely have rules stating that mem- bers of the professional library staff are classed as members of the faculty. In seven universities the members of the library staff are considered as a special professional group and are, therefore, set apart from other administrative employes. Of the twenty-six institutions remaining, ten definitely rate library workers, except some departmental heads, as administrative employes, while sixteen have no particular rank assigned to professional library members.

In the various college catalogs some employes of the library are listed among the faculty while others place them among those assigned to the heading "Other Employes of the University." Many have a separate listing headed "The Library Staff." Probably the last mentioned arrangement is best in any case, as the names of those having definite faculty rating can be put in their proper places in the faculty list, whether the latter is arranged alphabetically, by rank, or according to seniority.

\section{Director's Rank}

Judging from the replies, the librarian or director of the library is almost invariably given academic rank, usually as professor and in one or two cases as dean. While the rank of associate librarian or assistant librarian does not prevail in all institutions, these officials are counted as members of the faculty in twenty institu- 
tions while only eleven universities include heads of library departments among the faculty. So much for the statistical side.

\section{Librarians' Opinions}

The comments made in letters received on this apparently very undecided question are highly quotable. A great difference of opinion prevails on the question as to whether the library worker should be rated as a teacher or as an administrative employe. Among those with decided negative opinions on the subject I may cite three librarians. One states that "it is easier for librarians to retain their self respect as librarians, which they are, rather than as members of the faculty, which they are not." Another writes: "Library work in technical lines is not academic work. This does not mean that it is worse or better; it is merely other." Another states the problem clearly: "Here those who teach are members of the faculty and those who do not are administrative officers, and that is all there is to it." Still another contributes this thought: "I can see no real analogy between the work of librarians and that of the faculty."

Directly opposite opinions were forcibly expressed by several, each giving cogent reasons for his stand on the question. One librarian who has given much study to the matter states his position positively: "I am opposed to the tendency apparent in some quarters to class all library staff members as administrative.... The conclusion seems inescapable that whatever dignity may attach to an 'administrative' official is limited to himself and in the minds of others almost inevitably results in the classification of his assistants as clerks." Another states his argument flatly: "I see no reason why all members of my professional staff should not be given the same standing in the university community as a teacher." Still another cites the fact that "the problem is different from the business organization ... . because of the essential connection of the library staff with the teaching and research program." In one large institution the librarian writes that he has always resisted the implication that members of the library staff are "stenographers, although they do use typewriters." The fact that "members of the staff contribute enough to the educational process to warrant their recognition," leads another librarian to argue for faculty status for his professional staff.

\section{Few Universities Have Regulations on Subject}

In twenty-six of the thirty-seven institutions studied no definite written specific regulation covers the subject. Many let well enough alone and, as one librarian states it, the "way out of the headache is to ignore the problem." Where librarians have satisfactory conditions, are treated liberally in the matter of sick leave and vacations, are included in provisions for group insurance and retirement pensionsthe question is never a live one, but they naturally prefer that the position of staff members be well esteemed and do not like to see their several names scattered alphabetically in a list several pages long headed "Other Employes of the University." Some institutions of higher education open only to men have only men on their faculty so women on the library staff could not well be ranked as faculty in such places. In many schools there seems to be considerable disinclination to enlarge the faculty list by inclusion of names from the large nonteaching groups. 
Among the latter are laboratory assistants, medical technicians, etc., who are technically trained like professional librarians, but do not actually teach. A librarian writes in this regard: "I doubt very much whether we shall be considered 'scholars and gentlemen' until we have the same tags for the same amount of work as our teaching brothers and sisters." So the matter of assigning precise rank for all professional members of the staff would be a hard task indeed.

\section{Theoretical Dignity}

Even though statutes are not specific in regard to status of members of library staffs in the academic hierarchy, there are certain disadvantages accruing to being ranked as faculty. One man states it clearly: "Long years ago against my better judgment, I yielded to the feeling then ripe among the members of the professional staff and tried to secure for them the inestimable privilege of walking in cap and gown in the academic procession at commencement." Another in explaining that he is the only one connected with the library who is considered as a member of the faculty states: "I am the only member of the staff who has faculty rank and I enjoy the theoretical dignity of a full professorship and a vote at the monthly faculty meetings. ... In the commencement procession I march fairly near the front of the line, with the earliest division (agriculture), the arrangement within divisions being the tallest men first!"

Some universities seem to have solved this problem satisfactorily by setting up the library staff as a "separate professional group" rather than as faculty or administrative employes. Because of the high requirements in some institutions for rank of instructor it would seem to be inadvisable to attempt to start a beginning assistant, fresh from library school, at this grade. The whole problem would seem best solved by some such statute as is in force at Columbia University which reads: "Library Staff. Members of the Library staff shall be classified as professional and nonprofessional and assigned to appropriate grades of service within each group. Permanent members of the professional staff will rank with officers of instruction or officers of administration in respect to academic privileges." In the statutes of the University of Illinois there is the statement that members of the staff "may be given appropriate academic rank." Such a regulation, setting up the library staff as a definite professional group, would be satisfactory to those who are "yet to be convinced that faculty ranking is necessary or desirable for librarians." At the same time, it would answer the objection of the librarian who does not like his people being called a mere part of the "hired help."

The psychological questions involved are perhaps most important of all, so all can agree, I believe, to any regulation that recognizes the place of the library staff in the educational institution and, at the same time, gives proper dignity to their work. We may not be teachers by title, but we perform an indispensable service for which we have been specially trained. 